\title{
MATING HABITAT OF A TUNDRA STONEFLY IN NORTHERN SASKATCHEWAN
}

\author{
F.M. ATTON, 412 Leslie Avenue, Saskatoon, Saskatchewan. S7H $2 Z 1$
}

There are five common tundra stoneflies ${ }^{5}$ of which three species have been recorded from Saskatchewan. ${ }^{2}$ Diura bicaudata adults were collected for the first time in Saskatchewan at Patterson Lake on 27 June 1986 . The only previous record was a single nymph from Wollaston Lake, collected in 1956. The males are brachypterous (short winged), and four specimens were average length $12.4 \mathrm{~mm}(11.7-13.3 \mathrm{~mm})$. Five female specimens averaged $18.9 \mathrm{~mm}$ (18.4 - 19.3 $\mathrm{mm}$ ). Measurements are as defined in Dosdall and Lehmkuhl. ${ }^{2}$

Patterson Lake ( $59^{\circ} 56^{\prime} \mathrm{N} 102^{\circ} 19^{\prime} \mathrm{W}$ ) is in the northeastern corner of Saskatchewan surrounded by sub-arctic boreal forest; the vegetation was scattered black spruce and very thick sphagnum moss at the collection site. As we approached by air on 23 June 1986, Hasbala Lake (about 16 kilometers to the east) was seen to be two-thirds covered by ice. Patterson Lake was reported to have been free of ice on 18 June 1986 . The shore of this precambrian lake was a rampart of medium to large-sized boulders with flooded vegetation that was considerably damaged by the recent spring ice movement. Temperatures were $3-10^{\circ} \mathrm{C}$ at night and $18-20^{\circ} \mathrm{C}$ at midday.

Diura bicaudata specimens were collected from a few dead spruce stumps distributed 2 - $10 \mathrm{~m}$ from the lakeshore. When the dry and broken bark was pulled off, numbers of mating pairs, all facing upward, and one or two additional males were discovered, from $15-30 \mathrm{~cm}$ above ground level. In one stump there were at least 8 pairs in copulo. On being exposed to light, the insects seemed stunned for 2 or 3 seconds, then turned and ran or fell downward and went as deep as possible into the nearest crevice. The environment under the bark was moist but not wet. Two females were seen on the underside of alder leaves hanging over the water.

This unique mating habitat of Diura bicaudata may help the understanding of some features of the behavior of this species. Brinck reports that emergence takes place among stones on the shore at night or in early morning. ${ }^{1}$ In other stoneflies the males are frequently seen running about searching for females at the lakeshore, but Brinck did not see this behavior for $D$. bicaudata. ${ }^{1}$ The insects apparently leave the shore quickly to seek suitable cover and males do not display the searching behavior of other species. The mating habitat of $D$. bicaudata in the arctic barren grounds, where there are no tree stumps, will be interesting to explore. An arctic stonefly seeking a cryptic mating site may be an adaptation to an environment where protection from wind is largely lacking. On the breezy shore of a lake at Rankin Inlet, in the low arctic, I was impressed that large numbers of another tundra species, Arcynopteryx compacta refused to fly, but crawled among the low vegetation.

The considerable numbers of mating pairs in each stump imply some effective method of communication or attraction to the mating site. Some stonefly males drum, but mostly in the presence of females before or after mating. Drumming 
has not been observed by $D$. bicaudata. ${ }^{1}$ Considering the distance from the shore $(10 \mathrm{~m})$ and the cryptic position of the males, as well as ambient forest noise, an auditory signal would seem a poor method of attraction. For some other stoneflies Hynes concludes that "attraction seems to be due to some substance extruded by the female." ${ }^{4}$ Perhaps the females, capable of flight, first find the preferred mating habitat, then signal the location to males by a chemical signal. There seems to be no other mention of pheromone proáuction by stoneflies.

The observed nearly equal numbers of males and females suggests that $D$. bicaudata males do not emerge earlier than the females, as in many species of stoneflies. This agrees with the conclusion reached by Brinck. ${ }^{1}$ The main emergence of this species in central Sweden is in June, which corresponds with the appearance of the Patterson Lake population in 1986.

\section{Acknowlegements}

Thanks are given to Mr. L. Dosdall for confirming the identification of this species and for making available helpful literature.

Special thanks are extended to the Saskatchewan Natural History Museum for providing the opportunity to visit Patterson Lake, and especially to D. Baron and K. Roney for their assistance.

1 BRINCK, P. 1949. Studies on Swedish stoneflies. Oposcula Entomologica, Supplement II. $250 \mathrm{pp}$.

2 DOSDALL, L. and D.M. LEHMKUHL. 1979. Stoneflies (Plecoptera) of Saskatchewan. Quaestiones Entomologicae 15:3-116.

3 HYNES, H.B.N. 1941. The taxonomy and ecology of the nymphs of British Plecoptera with notes on the adults and eggs. Trans. R. Ent. Soc. London, V. 91 Pt. 10.

4 HYNES, H.B.N. 1970. The ecology of running waters. University of Toronto Press, Toronto.

5 RICKER, W.E. 1964. Distribution of Canadian stoneflies. Gewasser and Abwasser 34/35:50-71.
CHRISTMAS BIRD AND MAMMAL COUNTS

Count period is from Thursday 17 December 1987 to Sunday 3 January 1988, inclusive. Count area should be a circle $24 \mathrm{~km}$ (15 mi.) in diameter. Counts must be a minimum of 3 hours in duration. Count forms will be mailed to compilers who submitted counts in 1986. Anyone else wishing to send in a count please write for forms to:

\section{Mary 1. Houston}

863 University Drive

Saskatoon, Saskatchewan

S7N 0J8

Reports of counts should be sent to Mary Houston as soon as possible after they are taken. To be included in the report in the March 1988 Blue Jay they must reach Mary by 8 January 1988 at the very latest.
NORTHERN FOREST OWL SYMPOSIUM PROCEEDINGS

The proceedings of the Northern Forest Owl Symposium held in Winnipeg 3-7 February 1987 are now available from Rocky Mountain Forest and Range Experiment Station, Fort Collins, Colorado, 80526 as General Technical Report $\mathbf{R M - 1 4 2 . ~ T h e s e ~ a r e ~ f r e e ~ o f ~ c h a r g e . ~}$

\section{ENDANGERED SPECIES IN THE PRAIRIE PROVINCES}

The proceedings of the workshop on Endangered Species in the Prairie Provinces held in Edmonton 24-26 January 1986 are now available as Natural History Occational Paper No. 9 of the Provincial Museum of Alberta. These are available from Edmonton Natural History Club, Box 1582, Edmonton, Alberta, T5J 2N9 for $\$ 10.00$ each. 